\title{
Development and Evaluation of an Indirect ELISA: Serological Survey to Detect Specific Antibodies to Bovine Herpesvirus 4
}

\author{
Ernesto Renato Krüger ${ }^{1}$, Tânia Regina Penha ${ }^{2}$, Fernanda Cristina Hummelgen ${ }^{3}$, Jorge \\ Bacila Agottani $^{2}$, Demétrio Reva ${ }^{4}$, Robson Gonçalves ${ }^{4}$ and Vanete Thomaz-Soccol ${ }^{{ }^{*}}$ \\ ${ }^{1}$ Centro de Diagnóstico Marcos Enrietti ; Curitiba - PR - Brasil. ${ }^{2}$ Instituto de Tecnologia do Paraná - Curitiba- \\ $P R-$ Brasil. ${ }^{3}$ Universidade Tuiuti do Paraná; Curitiba $-P R-$ Brasil. ${ }^{4}$ Biogeneses Bagó Saúde Animal Ltda; \\ Curitiba - PR - Brasil. ${ }^{5}$ Universidade Federal do Paraná; Programa de Doutorado em Processos Biotecnológicos; \\ Centro Politécnico; Curitiba $-P R-$ Brasil
}

\begin{abstract}
The aim of this work was to develop and evaluate an indirect enzyme-linked immunosorbent assay (ELISA) and made a serological screening for specific antibodies to BoHV-4. Bovine serum samples were collected from different Brazilian states and evaluated for the presence of antibodies for BoHV-4 and BoHV-1. The serological results obtained showed that the indirect ELISA assay could be applied for the detection of specific antibodies for BoHV-4. The ELISA test allowed concluding that BoHV-4 is present in bovines in every Brazilian state from which serum samples were collected. The ELISA assay here standardized proved to be useful for the epidemiological studies and showed a positivity range from 1.8 to $66 \%$ in Brazil.
\end{abstract}

Key words: BoHV-4, serology, diagnostic, cattle, epidemiology

\section{INTRODUCTION}

Bovine herpesvirus-4 (BoHV-4) is a Gammaherpesvirus that infects cattle. It is a member of Rhadinovirus genus as determined by gene arrangement studies and phylogenetic analysis (Zimmermann et al. 2001). This virus has been associated with several reproductive disorders in the cows, such as postpartum metritis and abortion (Czaplick and Thiry 1998).

Experimental BoHV-4 pathogenesis is matter of controversy, since different strains isolated from the infected cattle show varying outcomes of clinical manifestations and are neither uniform nor reproducible. The Koch postulates only partially fulfill and leaves room to wonder if this virus is a true pathogen or not. Besides this conundrum, scientific curiosity has driven the search for an evolutionary explanation for this virus, because in the virus's world, it is an unique example of lateral transfer of a gene that encodes the core 2 beta-1,6-N-acetylglucosaminyltransferase

$(\mathrm{B} 1,6 \mathrm{GnT})$ protein, an enzyme that has implications for the host immune system evasion (Markine-Goriaynoff et al. 2003a).

Several studies have been have made to detect the BoHV-4 (Frazier et al. 2001, 2002, MarkineGoriaynoff et al. 2003b; Deim et al. 2007; Elhassan et al. 2011; Peréz et al. 2011) and varying prevalence rates ranging from 4 to $50 \%$ in Europe (Luini et al. 1985, 1986; Truman et al. 1986; Wellemberg et al. 1999; Essmail et al. 1999;

*Author for correspondence: vanetesoccol@gmail.com 
Monge et al. 2006), 14 to $70 \%$ in Africa (Kaminjolo et al. 1972; Rweyemamu et al. 1973; Theodoridis 1978; Eyanga 1989; Rossiter et al. 1989; Marchot et al. 1991; Woldemeskel et al. 2000; Elhassan et al. 2011), 2 to $88 \%$ in the USA (Potgieter and Mare 1971; Phillips et al. 1983, 1989; Naeem et al. 1989; Guo et al. 1998; Kruger et al. 1991), 8.9 to $23.3 \%$ in Asia (Kwang 1999; Asano et al. 2002); 69\% in the Middle- East (House et al. 1990; Gur et al. 2010) and $84.4 \%$ of animals in Serbia (Nikolin et al. 2007) have been reported. In Brazil, studies about BoHV-4 are still scarce. Recently, Costa et al. (2011) in Minas Gerais related the presence of BoHV-4 in 14 fragments of the Central Nervous System (CNS) in the cattle, which died presenting neurological signs.

Use of diagnostic serology as a tool to identify the BoHV-4 infection is still cumbersome, and there is no standard methodology to categorize the infections in animals. Serum neutralization (SN) has been used to generate binomial results, positive and negative, or titers for some animal herpes viruses, but not for the BoHV-4. SN is not practical tool, because the virus induces very low or absent antibody titers in both naturally and experimentally infected animals (Dubuisson et al. 1988). An endometriotropic strain was found to be useful for SN assays because it was capable of generating antibody titers that ranged from 1:8 to 1:32 (Frazier et al. 2002). Traditionally, indirect immunofluorescence has been the technique of choice, despite its drawbacks, when a large number of samples are to be evaluated (Osorio et al. 1985; Dewals et al. 2005). To detect the specific antibodies for BoHV-4, complement fixation, dot immunobinding and immunoperoxidase methods have also been employed (Guo et al. 1998; Essmail et al. 1999; Wellemberg et al. 1999; Monge et al. 2006).

Enzyme-linked immunosorbent assay (ELISA) is a powerful and practical technology for the serological studies and has been used to detect the reactive antibodies to a myriad of animal pathogens. Its use in seroepidemiological studies to identify the specific antibodies against BoHV-4 has been documented (Edwards and Newman 1985; Metzler and Wyler 1986; Czaplick and Thiry 1998; Asano et al. 2002).

In Brazil, Krüger et al. (2014) isolated and characterized a BoHV-4 strain from a cow suffering from the postpartum metritis to better understand the BoHV-4 implication in the wide- ranging reproductive clinical manifestation. It is necessary to develop a practical and efficient methodology capable of screening BoHV-4 infection in the enormous cattle population on a nation-wide basis. Thus, the aim of this work was to study the development and evaluation of an indirect ELISA and its application in a serological survey to identify specific antibodies for BoHV-4 in cattle.

\section{MATERIAL AND METHODS}

\section{Cell culture}

A primary cell culture was obtained from the bovine fetal tracheal epithelium and the lineage established was named TraFB. These cells were grown in F10-199 medium (Sigma, MI, USA), plus fetal calf serum (FCS, 5\%) and 10\% tryptose broth phosphate (TPB). The medium was supplemented with $100 \mathrm{UI} / \mathrm{mL}^{-1}$ penicillin, 100 $\mu \mathrm{g} / \mathrm{mL}^{-1}$ streptomycin and $2.5 \mu \mathrm{g} / \mathrm{mL}^{-1}$ fungizon as antimicrobials.

\section{Virus Strains}

The BoHV-4 strain isolated by Kruger et al. (2014) was used for the serum neutralization and ELISA antigen production. The BoHV-1 Los Angeles strain was used for the serum neutralization and ELISA antigen production to study the specificity.

\section{Serum Samples}

A collection of 1,810 serum samples was made from the bovines of 13 different Brazilian states. The animals belonged from beef and dairy cattle farms.

\section{Serum Neutralization (SN)}

For SN neutralization the protocol established by Bitsch (1978) was followed. In brief, serum was inactivated at $56^{\circ} \mathrm{C}$ for $30 \mathrm{~min}$ and then diluted to $1: 2$ and $1: 4$ in $50 \mu \mathrm{L}$ of maintenance medium $(\mathrm{MM})$, which was the same as the growth medium but without FCS and TPB. Fifty microliters of each virus suspension that contained 100 $\mathrm{TCID}_{50} / 50 \mu \mathrm{L}$ was added to each individual well and incubated at $4^{\circ} \mathrm{C}$ overnight. One hundred microliters of the cell suspension at a concentration of $3 \times 10^{5}$ cells $/ \mathrm{mL}$ was added to each well. The plates were incubated at $37^{\circ} \mathrm{C}$ in a $5 \% \mathrm{CO}_{2}$ atmosphere for five days for BoHV-1 and seven days for BoHV-4. Each plate was read every alternate day to detect specific antibodies for both the viruses. 


\section{ELISA Antigen}

For ELISA antigen production, the same procedure was used for both the BoHV-4 and BoHV-1. Roller bottles were seeded with TraFB cells. When the monolayers reached $90 \%$ confluence, the bottles were inoculated either with $10 \mathrm{~mL}$ of $10^{-3}$ $\mathrm{TCID}_{50 /} / 50 \mu \mathrm{L}$ of BoHV-4 strain or with $10^{-5}$ $\mathrm{TCID}_{50} / 50 \mu \mathrm{L}$ of BoHV-1, which was approximately the same $100 \mathrm{TICD}_{50}$ that was used in the serum neutralization assay. The time consuming multiplicity of infection experiments were not performed for this purpose. Bottles were incubated for at $37^{\circ} \mathrm{C}$ for $1 \mathrm{~h}$, then $50 \mathrm{~mL}$ of MM was added. To remove the cell debris, the medium was centrifuged at $10,000 \times \mathrm{g}$ for $20 \mathrm{~min}$. The suspension was then concentrated to $1 / 10$ of the original volume in an Amicon filter, with a 10,000 nominal molecular weight limit membrane. The concentrated virus was then applied onto a 30\% sucrose cushion and centrifuged at 100,000 xg for $1.5 \mathrm{~h}$. The virus pellet was re-suspended in TEN buffer $(100 \mathrm{mM} \mathrm{NaCl}, 10 \mathrm{mM}$ Tris and $1 \mathrm{mM}$ EDTA) and submitted to three ultra-sonication cycles (UNIQUE®), $15 \mathrm{~s}$ each, $20 \mathrm{KHz}$, at a power of 70 watts and was then stored at $-80^{\circ} \mathrm{C}$ until use.

\section{Indirect ELISA Standardization}

After a checkerboard titration was performed, the antigen titer was defined and $50 \mu \mathrm{L}$ of each preparation of virus antigen that was diluted 1: 400 in carbonate - bicarbonate buffer $(0.15 \mathrm{M}$ and 0.35 $\mathrm{M}$, respectively, $\mathrm{pH}$ 9.6) and added to each well. The plates were incubated at $4^{\circ} \mathrm{C}$ overnight or at $37^{\circ} \mathrm{C}$ for $2 \mathrm{~h}$ and subsequently washed four times with buffer $\left(0.15 \mathrm{M} \mathrm{NaCl}, 1.8 \mathrm{mM} \mathrm{Na}_{2} \mathrm{HPO}_{4}, 8.5\right.$ $\mathrm{mM} \mathrm{NaH}{ }_{2} \mathrm{PO}_{4}, 0.5 \mathrm{~mL}$ Tween 20, $\mathrm{pH} 7.2$ ); then blocked with $100 \mu \mathrm{L} /$ well of blocking buffer $(0.15 \mathrm{M} \mathrm{NaCl}, 0.05 \mathrm{M}$ Trizma, $0.001 \mathrm{M}$ EDTA, $0.5 \mathrm{~mL}$ Tween 20 and $3.0 \% \mathrm{BSA}$ ), $\mathrm{pH} 7.2$ at $37^{\circ} \mathrm{C}$ for $1 \mathrm{~h}$. The sera were diluted $(1: 25)$ in blocking buffer and $50 \mu \mathrm{L}$ of each dilution were added in duplicate to the wells. Positive and negative control sera were included in each test plate. The plates were then incubated at $37^{\circ} \mathrm{C}$ for $1 \mathrm{~h}$, washed again as above and $50 \mu \mathrm{L}$ of an appropriate dilution of rabbit anti-bovine $\operatorname{IgG}$ conjugate (1:3.200 in blocking buffer) were added to each well. The plates were again incubated at $37^{\circ} \mathrm{C}$ for 1 $\mathrm{h}$ and again washed. The reaction was developed by the addition of $50 \mu \mathrm{L}$ of substrate/chromogen solution $\left(0.4 \mathrm{mg} \mathrm{mL}^{-1}\right.$ of OPD in $0.05 \mathrm{M}$ of citric acid, plus $0.03 \% \mathrm{H}_{2} \mathrm{O}_{2}$ ) to each well. After $15 \mathrm{~min}$ of incubation, the reaction was stopped by the addition of $50 \mu \mathrm{L}$ of $1 \mathrm{~N} \mathrm{H}_{2} \mathrm{SO}_{4}$. The optical density was determined in a spectrophotometer with a $492 \mathrm{~nm}$ wavelength filter. The mean optical density (OD) of each serum was calculated using the following equation:

Mean Optical Density of Sample (OD):

OD positive control - OD negative control

\section{Statistical Analyses}

The experimentally determined indirect ELISA values were analyzed using Pearson correlations, percentage of global concordance and the nonweighted Kappa index. The frequency of ELISA results was analyzed using the Chi-squared and Ztest probabilities. Statistical significance was defined as $\mathrm{p}<0.05$.

\section{RESULTS}

\section{Serum Neutralization}

The standard serum neutralization assay was performed to determine the positive and negative control sera for BoHV-4 and BoHV-1, whose results were then compared to those obtained in the ELISAs. It was intended to take advantage of the well-established diagnostic serology routine to set a collection of sera containing a broad spectrum of antibodies titers to BoHV-1 (SN titers from 1:64 to 1:256) and also negative sera. For BoHV-4, as expected, few positive samples were identified that had titers of 1:2 or 1:4, and many of them were negative.

\section{Specificity Study}

92 sera were analyzed to study if there was any possibility of cross reactivity between the antibodies for the BoHV-4 and BoHV-1. Out of these, 20 sera were reactive in the BoHV-1 antigen (absorbance $\geq 0.400$ ) and negative in BoHV-4 ELISA (absorbance $\leq 0.200$ ). Two of these sera were reactive against both the viruses and three were reactive against BoHV-1 and had absorbance values that were in the grey zone $(\geq 0.201$ to $\leq 0.399$ ) for the reactivity against the BoHV-4. Only one sample was reactive to BoHV-4 and was not reactive to BoHV-1 (Table 1). This serum was used as positive control for the ELISA-based BoHV-4 epidemiological study. 
Table 1 - BoHV-4 Versus BoHV-1 indirect ELISA assays results in sera samples.

\begin{tabular}{|c|c|c|c|}
\hline \multicolumn{2}{|c|}{ ELISA absorbance } & \multicolumn{2}{|c|}{ RESULTS } \\
\hline BoHV-4 & BoHVI-1 & BoHV-4 & BoHV-1 \\
\hline 0.193 & 1.009 & $\mathrm{~N}$ & $\mathrm{P}$ \\
\hline 0.146 & 0.517 & $\mathrm{~N}$ & $\mathrm{P}$ \\
\hline 0.41 & 0.092 & $\mathrm{P}$ & $\mathrm{N}$ \\
\hline 0.011 & 0.458 & $\mathrm{~N}$ & $\mathrm{P}$ \\
\hline 0.129 & 0.919 & $\mathrm{~N}$ & $\mathrm{P}$ \\
\hline 0.202 & 1.014 & GZ & $\mathrm{P}$ \\
\hline 0.095 & 0.882 & $\mathrm{~N}$ & $\mathrm{P}$ \\
\hline 0.3 & 1.048 & GZ & $\mathrm{P}$ \\
\hline 0.011 & 1.136 & $\mathrm{~N}$ & $\mathrm{P}$ \\
\hline 0.05 & 0.760 & $\mathrm{~N}$ & $\mathrm{P}$ \\
\hline 0.078 & 1.268 & $\mathrm{~N}$ & $\mathrm{P}$ \\
\hline-0.05 & 0.514 & $\mathrm{~N}$ & $\mathrm{P}$ \\
\hline 0.41 & 1.014 & $\mathrm{P}$ & $\mathrm{P}$ \\
\hline 0.089 & 0.434 & $\mathrm{~N}$ & $\mathrm{P}$ \\
\hline 0.033 & 0.980 & $\mathrm{~N}$ & $\mathrm{P}$ \\
\hline-0.078 & 0.892 & $\mathrm{~N}$ & $\mathrm{P}$ \\
\hline-0.011 & 0.848 & $\mathrm{~N}$ & $\mathrm{P}$ \\
\hline-0.05 & 0.863 & $\mathrm{~N}$ & $\mathrm{P}$ \\
\hline 0.707 & 1.312 & $\mathrm{P}$ & $\mathrm{P}$ \\
\hline 0.092 & 0.98 & $\mathrm{~N}$ & $\mathrm{P}$ \\
\hline 0.308 & 2.089 & GZ & $\mathrm{P}$ \\
\hline-0.033 & 0.936 & $\mathrm{~N}$ & $\mathrm{P}$ \\
\hline 0.09 & 0.834 & $\mathrm{~N}$ & $\mathrm{P}$ \\
\hline 0.085 & 0.88 & $\mathrm{~N}$ & $\mathrm{P}$ \\
\hline-0.007 & 1.022 & $\mathrm{~N}$ & $\mathrm{P}$ \\
\hline-0.051 & 1.147 & $\mathrm{~N}$ & $\mathrm{P}$ \\
\hline
\end{tabular}

$\mathrm{N}$ - negative; $\mathrm{P}$ - positive; $\mathrm{GZ}$ - intermediate zone. ELISA values, $\mathrm{P} \geq 0.400 ; \mathrm{N} \leq 0.200 ; \mathrm{GZ}-0.201$ to 0.399 .

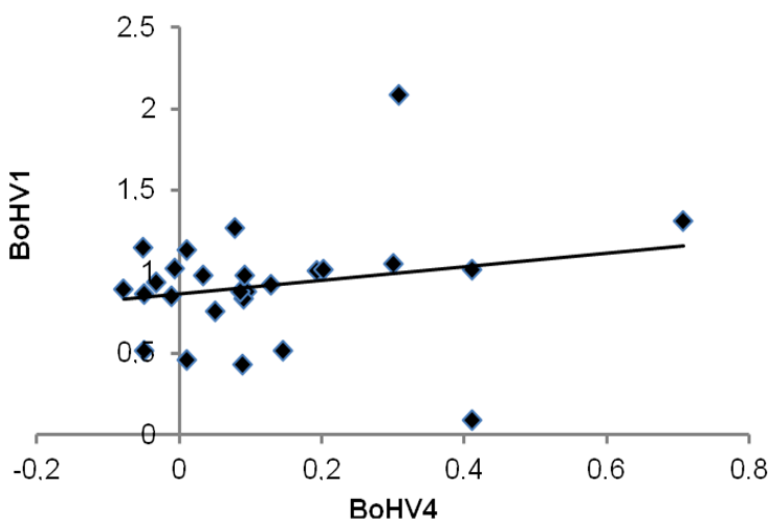

Figure 1 - Correlation plot for data of indirect ELISA assay of BoHV-1 against BoHV-4 R = 0.206; $\mathrm{p}=$ 0.311 ; Solid line is the best fit for the regression line.

\section{Cut-off determination}

To define a threshold value to distinguish the positive and negative samples, the ELISA values for the 201 sera samples that came from the 22 farms where there were no positive or intermediate results, were evaluated. A mean ELISA value of 0.014 for 114 of the samples and a negative mean value of 0.008 for 87 samples were obtained. The ELISA values were categorized as follow: negative serum $\leq 0.200$; positive serum $\geq 0.400$; intermediate zone 0.201 to 0.399 (Table 2).

Table 2 - Concordance analyses for the indirect ELISA assay for BoHV-4 versus BoHV1.

\begin{tabular}{llc}
\hline \multicolumn{2}{l}{ Comparisons } & Frequency \\
\hline \multirow{2}{*}{ Positive } & concordance & 2 \\
& discordance & 20 \\
\hline \multirow{2}{*}{ Negative } & concordance & 1 \\
& discordance & 0 \\
\hline \multirow{2}{*}{ Indexes } & $\%$ global concordance & $8.70 \%$ \\
& Kappa & $-9.03 \%$ \\
\hline
\end{tabular}

\section{BoHV-4 indirect ELISA and Epidemiological Analysis}

A total of 1,810 samples were evaluated to detect the presence of antibodies against BoHV-4. These samples were obtained from 315 different farmers in 13 Brazilian states. The overall presence of BoHV-4 antibodies could be summarized as follows: $366(20.2 \%)$ samples were positive, 1105 $(61.0 \%)$ were negative, and $339(18.7 \%)$ were in the intermediate zone. Table 3 presents a more detailed analysis and provides the sample size and state distribution.

For the indirect ELISA assay, high positivity frequency in $\mathrm{MG}, \mathrm{RJ}$, and $\mathrm{AM}$ and low positive frequency in SC, RS, RO, and MT was observed. High negative frequency was observed in SC, RS, RO, MS, and MT, and low negative frequency only in MG. For gray zone, high frequency in MG and low frequency in RS and MT (Table 2) (p < 0.05; Z-test) were observed.

Concordance analysis of the indirect ELISA assay data for the BoHV-4 compared to BoHV-1 indicated that there was an $8.7 \%$ of global concordance and a Kappa index of -9.03. The Pearson correlation analysis resulted in a correlation index of $0.206(\mathrm{p}=0.311)$ and a random error $\left(1-\mathrm{R}^{2}\right)$ of $95 \%$. These results suggested that no association was found between the BoHV-4 and BoHV-1 indirect ELISA assay. 
Table 3 - Results of indirect ELISA assay and statistical analyses.

\begin{tabular}{|c|c|c|c|c|c|c|c|c|c|c|c|c|}
\hline \multirow{2}{*}{ Brazil State } & \multicolumn{3}{|c|}{ Frequency } & \multicolumn{3}{|c|}{ Z-Test } & \multicolumn{3}{|c|}{ p } & \multicolumn{3}{|c|}{ Observations } \\
\hline & $\mathbf{P}$ & $\mathbf{N}$ & GR & $\mathbf{P}$ & $\mathbf{N}$ & GR & $\mathbf{P}$ & $\mathbf{N}$ & GR & $\mathbf{P}$ & $\mathbf{N}$ & GR \\
\hline MG & 157 & 156 & 129 & 9.21 & -12.77 & 6.48 & 0.0000 & 0.0000 & 0.0000 & $0>\mathrm{e}$ & $0<\mathrm{e}$ & o>e \\
\hline GO & 77 & 227 & 66 & 0.32 & 0.13 & -0.49 & 0.7515 & 0.8939 & 0.6222 & $\mathrm{O}=\mathrm{e}$ & $\mathrm{o}=\mathrm{e}$ & $\mathrm{o}=\mathrm{e}$ \\
\hline PR & 38 & 133 & 40 & -0.85 & 0.63 & 0.09 & 0.3948 & 0.5296 & 0.9280 & $\mathrm{O}=\mathrm{e}$ & $\mathrm{o}=\mathrm{e}$ & $\mathrm{o}=\mathrm{e}$ \\
\hline $\mathrm{SC}$ & 36 & 168 & 37 & -2.19 & 2.96 & -1.44 & 0.0283 & 0.0031 & 0.1490 & $0<\mathrm{e}$ & $0>e$ & $\mathrm{o}=\mathrm{e}$ \\
\hline BA & 13 & 40 & 11 & 0.02 & 0.24 & -0.32 & 0.9852 & 0.8086 & 0.7475 & $\mathrm{O}=\mathrm{e}$ & $\mathrm{o}=\mathrm{e}$ & $\mathrm{o}=\mathrm{e}$ \\
\hline SP & 12 & 56 & 14 & -1.29 & 1.38 & -0.39 & 0.0987 & 0.1686 & 0.6940 & $\mathrm{O}=\mathrm{e}$ & $\mathrm{o}=\mathrm{e}$ & $\mathrm{O}=\mathrm{e}$ \\
\hline RO & 11 & 89 & 17 & -3.01 & 3.44 & -1.20 & 0.0026 & 0.0006 & 0.2287 & $0<\mathrm{e}$ & $0>e$ & $\mathrm{o}=\mathrm{e}$ \\
\hline RJ & 7 & 8 & 2 & 2.16 & -1.19 & -0.74 & 0.0307 & 0.2346 & 0.4596 & o>e & $\mathrm{O}=\mathrm{e}$ & $\mathrm{o}=\mathrm{e}$ \\
\hline $\mathrm{AM}$ & 6 & 3 & 0 & 3.48 & -1.71 & -1.44 & 0.0005 & 0.0874 & 0.1488 & $0>e$ & $\mathrm{o}=\mathrm{e}$ & $\mathrm{o}=\mathrm{e}$ \\
\hline MS & 3 & 52 & 10 & -3.19 & 3.19 & -0.70 & 0.0014 & 0.0014 & 0.4815 & $0<\mathrm{e}$ & $0>e$ & $\mathrm{o}=\mathrm{e}$ \\
\hline RS & 3 & 116 & 7 & -5.17 & 7.40 & -3.93 & 0.0000 & 0.0000 & 0.0001 & $0<e$ & $0>e$ & $0<\mathrm{e}$ \\
\hline DF & 2 & 8 & 2 & -0.31 & 0.40 & -0.18 & 0.7584 & 0.6889 & 0.8542 & $\mathrm{o}=\mathrm{e}$ & $\mathrm{o}=\mathrm{e}$ & $\mathrm{o}=\mathrm{e}$ \\
\hline MT & 1 & 49 & 4 & -3.41 & 4.54 & -2.17 & 0.0006 & 0.0000 & 0.0304 & $0<\mathrm{e}$ & $0>e$ & $0<\mathrm{e}$ \\
\hline Total & 366 & 1105 & 339 & & & & & & & & & \\
\hline
\end{tabular}

$\mathrm{P}$ - positive; $\mathrm{N}$ - negative; GR - gray zone; $\mathrm{p}$ - probability for the null hypothesis; $\mathrm{o}$ - observed frequency; $\mathrm{e}$ - expected frequency. Brazil States $\rightarrow$ MG (Minas Gerais), GO (Goiás), PR (Paraná), SC (Santa Catarina), BA (Bahia), SP (São Paulo), RO (Rondônia), RJ (Rio de Janeiro), AM (Amazonas), MS (Mato Grosso do Sul), RS (Rio Grande do Sul), DF (Distrito Federal), MT (Mato Grosso). $\chi^{2}=249.18 ; \mathrm{df}=24 ; \mathrm{p}=0.0000$

\section{DISCUSSION}

Since their discovery, antibodies have been known to play a major role in host-pathogen interactions, health and disease pathogenesis, and in the coevolution of different biological systems as a result of their specific association with critical epitopes. Based on the exploration of interactions between the antibodies and other protein molecules, several methodologies have been developed to rapidly and reliably identify a cause-and-effect connection between the infection and the clinical manifestation of disease. ELISA is an ideal serological test with adequate sensitivity and specificity, and it allows the generation of data to support rational decision-making quickly. Previous studies have suggested that indirect ELISA can be utilized for the detection of specific antibodies to BoHV-4, although there are still some obstacles to overcome, such as the difficult task of rigorously defining the lowest cut-off value and eliminating the potential cross reactivity with other bovine herpesvirus (Mohanty et al. 1984).

To circumvent these limitations, a strategy was adopted that was believed to be appropriate and feasible to present time working conditions. First, there was a need to identify the truly positive and negative sera for BoHV-4 in order to have ELISA's positive and negative controls. SN was chosen to find them, because through this technique, the positive serum was supposed to have predominantly IgG antibody class. Once the ELISA methodology was standardized, there was a need to know what would be the Mean Optical Density of the negative sera to rationally define a cut-off value on the experimental basis. To do that, 201 samples were selected from the farms that were included in this work whose results were convincingly negative that there were no intermediate or positive results. This showed a mean ELISA value of 0.014 for 114 samples and negative 0.008 for 87 samples. Considering these data, an ELISA value up to 0.200 was set as an indicative of a negative result.

The second major concern was the possibility of cross reactivity between the antibodies for the BoHV-4 and BoHV-1. As discussed in the results, there was no evidence that specific BoHV-1 antibodies interfered with the ELISA results for the BoHV-4. This finding was identified in a unidirectional fashion, in that 17 sera out of 92 analyzed were strong positive to BoHV-1 and negative to BoHV-4. Three of them were weak positive to the former and negative to the latter (Table 1). Two of the sera were positive to both the viruses, which were considered as prudent to characterize these samples as from the animals infected with both the viruses, as discussed 
previously by Metzler and Wyler (1986). This seemed to be reasonable, since experimentally there was no evidence of cross reaction. Considering that there was yet no method to establish a critical value with which one could determine the presence or absence of specific antibodies for BoHV-4 and considering the possibility of experimental error and the biological variables among different animals, it was reasonable to include an intermediate zone, with values that ranged from 0.201 to 0.399 . It was hypothesized that the vast majority of the sera that fell within this category were actually positive, particularly those samples that were gathered from the farms with other cattle that harbored reactive antibodies. This was based upon the realization that the majority of ELISA values of these samples agglutinated in the vicinity of the upper limit fixed to the intermediate zone.

These serological results allowed concluding that BoHV-4 infected the cattle in Brazil. Although the sample size was quite small for some areas, it could be assumed that this disease was endemic in some regions of the country and the frequency ranged from 1.8 to $66 \%$. This serological study could pave the way for future inventory type measure, such as prevalence, because ELISA method has been standardized and proven to be useful for these epidemiological enquires. This work might also bring clinicians' attention to the pathologies that have been described as associated with BoHV-4 (Markine-Goriaynoff et al. 2003a), such as those mentioned by the farmers when they submitted the samples. These pathologies included abortions and heat repetitions and it was very interesting that nearly $100 \%$ of farms that had cases of placenta retention also had cattle that had reactive antibodies for the BoHV-4.

\section{ACKNOWLEDGMENT}

Authors are grateful to Professor Aguinaldo José do Nascimento for the statistical works and English revision.

\section{REFERENCES}

Asano A, Inoshima Y, Murakami K, Iketani Y, Yamamoto Y, Sentsui H. Latency and persistence of Bovine herpesvirus 4, strain B11-41, in bovine nervous tissue. $J$ Vet Med Sci. 2003; 65(1), 87-93.
Bitsch V. The p37 24 modification of the infectious bovine rhinotracheitis virus-serum neutralizationtest. Acta Vet Scand.1978; 19:497-505.

Costa GA, Vasconcelos AC, Bomfim MRA, Amorim HB, Lima GBL, Coelho FM, et al. Neurological disorder in cattle associated with Bovine herpesvirus4. Arq Bras Med Vet Zootec. 2011; v63(4):828-835.

Czaplick G, Thiry E. An association exists between bovine herpesvirus-4 seropositivity and abortion in cows. Prev Vet Med. 1998; 33: 235-240.

Deim ZL, Szeredi L, Egyed L. Detection of Bovine herpesvirus-4 DNA in aborted bovine fetuses. Can J Vet Res. 2007; 71: 226-229.

Dewals B, Gillet L, Gerdes T, Taracha ELM, Thiry E, Vanderplasschen A. Antibodies against bovine herpesvirus 4 are highly prevalent in wild African buffaloes throughout eastern and southern Africa. Vet Microbiol. 2005; 110:209-220.

Dubuisson J, Thiry E, Thasasso F, Bublot M, Pastoret PP. Biological and biochemical comparison of bovine herpesvirus 4 strains. Vet Microbiol. 1988; 16: 339349.

Edwards S, Newman RH. Detection of antibodies to bovid herpesvirus 4 by ELISA. Vet Microbiol. 1985; 10:149-154

Elhassan AM, Fadol MA, El-Hussein AM. Seroprevalence of bovine herpes virus-1, bovine herpes virus-4 and bovine viral diarrhea virus in dairy cattle in Sudan. Pak Vet J. 2011;31(4): 317-320.

Essmail M, Baker B, Collins J, Vandewoude S, Salman M, Hegazy AA. Dot immunobinding assay for detection of bovine herpesvirus 4 antibodies in rabbits. J Vet Invest. 1999; 11: 237-239.

Eyanga E, Jetteur P, Thiry E, Wellemans G, Dubuisson J, Van Opdenbosch E, et al. Research on antibodies against BHV-1, BHV-2, BHV-4, BVD-MD virus, bovine adenovirus $\mathrm{A}$ and $\mathrm{B}$, rotavirus and coronavirus in cattle in western Zaire: complementary results. Rev Elev Med Vet Pays Trop. 1989; 42:155-161.

Frazier K, Baldwin CA, Pence M, West J, Bernard J, Ligget A, et al. Seroprevalence and comparison of isolates of endometriotropic bovine herpesvirus 4. J Vet Diagn Invest. 2002; 14: 457-462.

Frazier K, Pence M, Mauel MJ, Liggett A, Hines ME, Sangster L, et al. Endometritis in postparturient cattle associated with bovine herpesvirus-4 infection: 15 cases. J Vet Diag Invest. 2001;13(6):502-508.

Guo WZ, Shen DT, Evermann JF, Gohram JR. Comparison of enzime-linked immunosorbent assay and a complement fixation test for detection of $\mathrm{IgG}$ to bovine herpesvirus 4 (bovine cytomegalovirus). Am J Vet Res. 1998; 49: 667-670.

Gür S, Dogan N. Yhe possible role of bovine herpesvirus type- 4 infection in cow infertility. Anim Sci J. 2010; 81:304-308. 
House JA, Wilson TM, Nakashly S, Karim IA, Ismail I, El Danaf N, et al. The isolation of Lumpy skindisease virus and bovine herpesvirus-4 from cattle in Egypt. $J$ Vet Diagn Invest. 1990; 2:111-115.

Kaminjolo JS, Mugera GM, Rosted AF. Isolation of a Herpes-type Virus from some tumors of Bovine origin. Zentralbl Veterinarmed[B]. 1972;19:626-632.

Krüger JM, Osborne CA, Goyal SM, Wickstrom SL, Johnston GR, Fletcher TF, et al. Clinical evaluation of cats with lower urinary tract disease. $\mathrm{J} \mathrm{Am} \mathrm{Vet} \mathrm{Med}$ Assoc. 1991; 199:211-216.

Kruger ER, Penha TR, Stoffelo D, Roehe P, CostaRibeiro M, Thomaz Soccol V. Bovine Herpesvirus 4 in Parana State, Brazil: case report, viral isolation, and molecular identification. Braz J Microbiol. 45(4):1513-1519.

Kwang MJ. Virus isolation and serological investigationof bovine herpesvirus type 4 in Taiwan. J Chin Soc Vet Sci. 1999;25:50-54.

Luini M, Fabbi M, Cervio G. Isolamento di un herpesvirus da lesioni erosive linguali del bovino. Estratto Sel Vet. 1985;26:1131-1133.

Luini M, Fioni E. Frequency of bovid-herpesvirus-4 (BHV-4) infection in cattle in Lombardia and Emilia Romana. Atti Societtà It Buiat. 1986;18:329-339.

Marchot P, Thiry E, Jetteur P, Leroy P. Serological survey on the prevalence of bovine type-4 herpesvirus infection in cattle in the Accra plains of Ghana. Rev Elev Med Vet Pays Trop. 1991;44:405406.

Markine-Goriaynoff N, Georgin JP, Goltz M, Zimmermann W, Broll H, Wamwayi HM, et al. The core 2 beta-1,6-N-acetylglucosaminyl transferasemucin encoded by bovine herpesvirus 4 was acquired from an ancestor of the African buffalo. J Virol. 2003; 77: 1784-1792.

Markine-Goriaynoff N, Minner F, Fayes K, Gillet L, Thiry E, Pastoret PP, et al. L'herpèsvirus bovin 4 . Ann Méd Vet. 2003;147: 215-247.

Metzler AE, Wyler R. Prevalence of bovine herpesvirus 4 in the Swiss cattle population and possible serologic cross reaction with bovine herpesvirus 1 (IBR/IPV virus). Schweiz Arch Tierheilkd. 1986; 128: 459-467.

Mohanty SB, Rockemann DD, Snyder DB. Serologic cross-reaction between bovine herpesvirus 1 and 4 by enzyme - linked immunosorbent assay. Microbiol.1984; 7: 179-186.

Monge A, Elvira L, Gonzales JV, Astiz S, Wellemberg GJ. Bovine herpesvirus 4 associated postpartum metritis in a Spanish herd. Res Vet Sci. 2006; 80: 120135.

Naeem K, Goyal SM, Werdin RE. Prevalence of bovid herpesvirus-4 and its antibody in cattle in Minnesota. Am J Vet Res. 1989;50:1931-1935.
Nikolin VM, Donofrio G, Milosevic B, Taddei S, Rodosavljevic V, Milicevic V. First Serbian isolates of bovine herpesvirus 4 (BoHV-4) from a herd with history of postpartum metritis. New Microbiol. 2007;30:53-57.

Osorio FA, Reed DE, Van Der Maater MJ, Metz CA. Comparison of the herpesvirus of cattle by DNA restriction endonuclease analysis and serological analysis. Am J Vet Res. 1985; 46: 2104-2109.

Pérez SE, Verna AE, Leunda MR, Favier PA, Ceriani $\mathrm{MC}$, Morán PE, et al. Occurrence of bovine herpesvirus type 4 DNA in Argentinean holstein cattle from Santiago del Estero, Argentina. Braz J Vet Res Anim Sci. 2011;48(6):454-463.

Phillips RM, Edwards AJ, Smith JC. The isolation of bovine herpesvirus 3 (DN-599) and a serological survey of a feedlot cattle for antibodies to this virus. $J$ Vet Diagn Invest. 1983;393-398.

Phillips RM, Nassar RF. A serological study of human herpesvirus simplex 1 and bovine herpesvirus 1, 2 and 4 in Kansas cattle. Bovine Pract. 1989;24:14-17.

Potgieter LN, Maré CJ. Assay and antigenic interrelationship of the recently isolated bovine herpesviruses, DN599, FTC and V11. Arch Gesamte Virusforch. 1974;46:238-247.

Rossiter PB, Gumm ID, Stagg DA, Conrad PA, Mukolwe S, Davies FG, et al. Isolation of bovine herpesvirus-3 from African buffaloes (Syncerus caffer). Res Vet Sci. 1989;46:337-343.

Rweyemamu MM, Loretu K. Isolation of "nonsyncytia-forming" herpes virus from cattle in Tanzania. J Comp Pathol. 1973;83:377-386.

Theodoridis A. Preliminary characterization of viruses isolated from cases epididymitis and vaginitis in cattle. Onderstepoort J Vet Res. 1978;45:187-195.

Truman D, Ludwig H, Storz J. Bovine herpesvirus type4: studies on the biology and spread in cattle herds and insemination bulls. $J$ Vet Med (series B). 1986;33:485-501.

Wellemberg GJ, Van Rooij EM, Maissan J, Van Oirschot JT. Evaluation of a newly developed immunoperoxidase monolayer assay for detection of antibodies against bovine herpesvirus 4. Clin Diagn Lab Immunol.1999;6: 447-451.

Woldemeskel M, Kebede E, Yegezu L, Potigieter LN. Prevalence of bovine respiratory syncytial virus (BRSV) and bovine herpesvirus-4 (BHV-4) in cattle from Ethiopia. Dtsch Tierarztl Wochenschr. 2000; 107:464-466.

Zimmermann W, Broll H, Ehlers B, Buhk HJ, Rosenthal A, Goltz M. Genome sequence of bovine herpesvirus 4, a bovine Rhadinovirus, and identification of an origin of DNA replication. $J$ Virol. 2001; 75:1186-1194. 